\title{
ANALYSIS OF TRANSLATION SHIFT IN THE INDONESIAN TRANSLATION DALIH PEMBUNUHAN MASSAL: GERAKAN 30 SEPTEMBER DAN KUDETA SUHARTO BY JOHN ROOSA OF AN ENGLISH DOCUMENT PRETEXT FOR MASS MURDER: THE SEPTEMBER 30TH MOVEMENT AND SUHARTO'S COUP D'ÉTAT IN INDONESIA
}

\author{
Sigit Suharjono *)
}

\begin{abstract}
ABSTRAK
Penerjemahan teks dari satu bahasa ke bahasa lain adalah praktek yang lazim ditemui dalam berbagai konteks wacana, baik yang bersifat akademik, nonakademik, formal maupun nonformal. Namun demikian, dalam teks target hasil terjemahan seringkali terdapat masalah ketidaksetaraan pada tingkat kata ataupun pada tingkat tekstual. Penelitian ini adalah kajian pustaka yang bertujuan untuk mengungkap masalah-masalah ketidaksetaraan dalam alih bahasa dari bahasa Inggris ke bahasa Indonesia. Sumber data, yaitu Dalih Pembunuhan Massal: Gerakan 30 September dan Kudeta Suharto yang merupakan alih bahasa oleh John Roosa dari dokumen bahasa Inggris Pretext for Mass Murder: The September 30th Movement and Suharto's Coup d'État in Indonesia. Data ketidaksetaraan terjemahan diidentifikasi, diklasifikasikan, dan dianalisis berdasarkan teori Category Shift oleh Catford (1965). Hasil analisis data menunjukkan bahwa ada beberapa masalah ketidaksetaraan dalam empat pergeseran kategori menurut teori Catford, yaitu pergeseran struktur, pergeseran jenis kata, pergeseran tingkat, dan pergeseran intrasistem. Pergeseran struktur merupakan kasus yang paling banyak terjadi.
\end{abstract}

\section{Kata kunci: translation, shift, non-equivalence, source text, target text}

\section{Introduction}

Translating a text from one language to another may often result in a problem level, for example, may arise because the word to be translated to the target language (TL) is related to a very specific culture in the source language (SL) which does not exist in the culture of the target language. Another problem at this level is that people of different languages may not have the same perception of entities outside the language. People of one language might think that two different entities in one language are not of different entities in their own language. This may be because they think either the two entities are not different or the difference is not of any importance that it does not need its own labeling. For example, Javanese think that beras and menir are two different things that need different labels. Unlike the Javanese, English would think that they are of the same thing, rice, or the difference between the two is not important that there shouldn't be different labels. To deal with these kinds of a problem, a translator tends to pick up the word in the source text (ST), use it in the target text 
(TT) and gloss it to let the message understood by the readers in the target language.

Problems of non-equivalence at other levels commonly originate from the translator's internal factors. A translator might lack competency in either the source language or the target language (TL) or both, or he might make his own intervention and make 'more than necessary contribution' (Machali, 2012:84). Cases of such problems are commonly found in the translation of literary work where a translator often interferes and makes adaptation to the existing values in the TL.

\section{Objective}

This study aims to reveal problems of non-equivalence based on the category shift proposed by Catford (1965) that may exist in the Indonesian translation Dalih Pembunuhan Massal: Gerakan 30 September dan Kudeta Suharto by John Roosa which is translated from an English document Pretext for Mass Murder: The September 30th Movement and Suharto's Coup D'état in Indonesia. In addition, this study also aims to find out whether Category Shift can cover every shift in the translation.

\section{Method}

The method of this study is a library research focusing on equivalence and nonequivalence in translation work. The source of data is the English translation of an Indonesian text Dalih Pembunuhan Massal: Gerakan 30 September dan Kudeta Suharto by John Roosa. The data collected in this study, the non-equivalence ranging from word to textual level found in the source of data, will be analyzed from the perspective of Category Shift based on the theory proposed by Catford (1965).

\section{Overview of the Literature}

Translation is both interesting and challenging. On the one hand, it is interesting in that no translator is able to translate back his/her translation into its original without any difference. The product of translation is always irreversible. This tells us that a translated text is not possible to be retranslated into its original language with exactly the same result as it was before being translated. House (2014:18) suggests that "reversibility/symetry is a myth in the translation context and that linguisticstructural knowledge of languages is not sufficient to account for the complex task of translation." Similarly, Baker (2011:7) states that back-translation can never be the same as the original.

On the other hand, translation poses challenges to translators in that the product of translation should be able to transfer the message communicated by the author in the source language into the target language whose vocabulary, structures, features, and 
Analysis of Translation Shift in The Indonesian Translation Dalih Pembunuhan Massal: Gerakan 30 September dan Kudeta Suharto by John Roosa of an English Document Pretext forMass Murder: The September 30th Movement and Suharto's Coup D'état in Indonesia (Sigit Suharjono)

cultures are of much different. At this point, translation often encounters problems of nonequivalences in various levels that it looks like impossible to transfer the whole message to the TT readers just as Baker (2011:7) suggests that translation seems to be an impossible task because languages never have sufficient similarities to express the same realities.

Differently, Hatim and Munday (2004:15), however, is optimistic that meaning can still be sufficiently communicated across languages. But, for this to be possible, meaning has to be comprehended not only in terms of what the ST conveys, but also and equally significantly, in terms of such variables as communicative purpose, target audience and purpose of translation. This indicates that a translator must have an adequate comprehension in both ST and TT of the message, communicative purpose, audience, and the purpose of translation.

Similarly, Nida \& Taber in Hatim \& Munday (2004:40) echoes that "Anything which can be said in one language can be said in another, unless the form is an essential element of the message." This clearly explains his belief that translation is viable, and that message can be wholly communicated from one language to another by finding equivalences from word level to textual level in the TT. Textual equivalence, according to Hatim and Munday (2004:27), is any text of the TL or portion of text which is considered to be the equivalent of a given SL text or portion of text. It is at this level that a translation should encompass what information is being communicated and what feelings or impact the text is intended to have on the readers of the TT (Larson, 1984:477).

The fact that every language is characterized by its own system of grammar and lexicon has always made shifts inevitable in the process of transfering meaning of the SL text into the TL text. Catford (1965:7382) introduced two kinds of shifts in translation: level shifts and category shifts. While the first is only possible to occur in the shifts from grammar to lexis and vice versa, Catford further explains that category shifts are likely to occur in four categories: structure-shifts, class-shifts, unit-shifts (rankchanges), intra-system-shifts.

Structure-shifts include not only changes in the order of elements of a sentence or phrase but also addition or subtraction of elements within a sentence or phrase. These are amongst the most common category shifts in translation. Class-shift, then, occurs when the translation equivalent of an SL item is a member of a different class from the original item. For example, in the translation of an English noun phrase a medical student into French un étudiant en médecine the lexical equivalent of the adjective medical is the noun médecine. Clearly shown in the example is 
that the adjective medical has shifted to noun médecine.

Unit-shift, based on this theory, refers to changes of rank - that is, changes from formal correspondence in which the translation equivalent of a unit at one rank in the SL is a unit at a different rank in the TL. This, for example, could be a shift from a word to a phrase or a phrase to a clause.

The last shift, intra-system shift, refers to any case where the shift occurs internally within a system, that is to say that the source language share the same system as the target language, say systems of number which employs singular and plural subject-verb agreement, but the translation of language $\mathrm{A}$ singular is language B plural and vice versa.

\section{Findings and Discussion}

Following are cases of nonequivalences where category shifts occur in the translation of Pretext for Mass Murder: the September 30th Movement and Soeharto's coup d'état in Indonesia by John Roosa. The problems are discussed in the order where they appear in the text.

\section{ST: Pretext for Mass Murder: The}

September 30th Movement and

Suharto's Coup d'État in Indonesia

TT: Dalih Pembunuhan Massal: Gerakan 30 September dan Kudeta Suharto

The structure-shift occurs here by the omission of an adverb (of place) at the end of the sentence. The translator deleted this information because the target readers are Indonesian people. In Baker's term this belongs to textual non-equivalence where substitution and ellipsis are strategies that a translator can employ to cover such problem.

2. ST: The truth about the usurpation must not be made apparent; it came about originally without reason and has become reasonable.

TT: Kebenaran tentang perebutan kekuasaan tidak boleh dibikin jelas; pada mulanya ia terjadi tanpa alasan tapi kemudian menjadi masuk akal.

Two shifts occur in the translation above. The first is structure shift. The change of position of the adverb 'originally' which is middle position in the source text into front position in the target text. In this case the translator use the fronting strategy to overcome the textual non-equivalence as explained by Baker. The replacement of the conjunction 'and' in the ST with 'tapi' in the TT, and the addition of the word 'kemudian' in the TT which does not exist in the ST are also structure-shifts which might lead to the shift of meaning. In addition to the structure shifts, unit shifts also occur, that is in the translation of 'has become' into 'menjadi' and 'reasonable' into 'masuk akal' in which a word in the ST has been translated into a phrase and vice versa. Here the translator uses substitution strategy to again cover the textual non-equivalence in the Baker's terminology. 
Analysis of Translation Shift in The Indonesian Translation Dalih Pembunuhan Massal: Gerakan 30 September dan Kudeta Suharto by John Roosa of an English Document Pretext forMass Murder: The September 30th Movement and Suharto's Coup D'état in Indonesia (Sigit Suharjono)

3. ST: For historians who have tried to make sense of the course of modern Indonesian $\quad$ history, a matter of some frustration is that the most enigmatic episode happens to be one of the most significant.

TT: Bagi sejarawan yang ingin memahami perjalanan sejarah Indonesia modern, hal yang terkadang menimbulkan rasa frustrasi ialah justru karena kejadian yang paling misterius ternyata merupakan salah satu babak kejadian yang terpenting.

The same case happens in the translation above - the structure-shifts and the unit-shift. However, the translator also chose to change the lexicons. Instead of using 'telah berusaha untuk' for 'have tried to', the translator chose to use 'ingin' which makes the meaning shift. Also, the use of an adjective clause 'yang terkadang menimbulkan frustasi' to translate a prepositional phrase 'of some frustration' is a unit-shift which involves a structure-shift, that is the addition of several elements in the TT.

\section{ST: Lieutenant Gen-eral Achmad Yani,} and five generals on his staff were

kidnapped from their homes in Jakarta and trucked to a desolate grove south of the city.

\section{TT: Letnan Jenderal Ahmad Yani dan} lima orang staf umumnya diculik dari rumah-rumah mereka di Jakarta, dan dibawa dengan truk ke sebidang areal perkebunan di selatan kota.

The choice to use 'dibawa dengan truk' for one word equivalent 'trucked' is a case of a unit-shift, and the use of 'areal' which is a noun to translate 'desolate' which is an adjective has led to a class-shift. The translator's choice to use 'dibawa dengan truk' as the equivalent for 'trucked' (though it is categorized as a unit-shift) is based on the contextual meaning that 'trucked' as used in the ST really carries the meaning of 'dibawa dengan truk'in the TT.

5. ST: The members represented a fairly wide spectrum of political opinion: Muslim politicians, midlevel Communist Party figures, journalists, women, and youth leaders.

TT: Para anggota mewakili aneka macam pandangan politik yang relatif luas: politisi Muslim, kader menengah PKI, wartawan, perempuan, dan pimpinan pemuda.

The intra-system shift occur several times in the translation of the sentence above. The translation of the plural nouns: members, politicians, figures, journalists, women, and leaders respectively into the singular nouns: anggota, politisi, kader, wartawan, perempuan, and pimpinan falls into the category of this type of shift. However, for this time again the shift does not change the message being communicated by the writer in the source text, and it is naturally acceptable 
in the target text. This kind of shift, the intrasystem-shift, is the least to occur in the translation of Pretext for Mass Murder: the September 30th Movement and Soeharto's coup d'état in Indonesia by John Roosa , and it is limited to the shift of the system of number wherein the singular form in the Indonesian language is translated into the plural form in English.

The structure-shifts are the most to happen through the TT. This is due to the fact that almost every shift involves the shift in structure as can be seen in the following examples of cases collected from the data source.

a. Para penculik membunuh Yani dan dua jenderal lainnya pada saat penangkapan berlangsung.

The use of adverb clause "pada saat penangkapan berlangsung' which consists of a relative pronoun + subject + predicate as the translation equivalent of a prepositional phrase 'in the course of capturing them' is a case of unit shift. That a clause changes to a phrase is a case of a unit-shift in which the translation equivalent of a unit at one rank in the SL is a unit at a different rank in the TL (Hatim \& Munday, 2004, p. 146). Following that change is a structure-shift where the structure of capturing them with the structure of verb + object changes to penangkapan berlangsung, which is subject + verb.

b. Seorang letnan, yang salah tangkap dari rumah jenderal ketujuh yang lolos dari pencu-likan, menemui nasib dilempar

\section{ke dasar sumur yang sama.}

The translation equivalen of the threeword noun phrase watery subterranean end which consists of adjective + adjective + noun into a two-word noun phrase dasar sumur which consist of noun + noun shows a class-shift in that subterranean which is an adjective has changed to dasar which is a noun, and it also shows a structure-shift in that the word watery in the phrase watery subterranean end has to be deleted and replaced by a two-word phrase dasar sumur which implies the presence of water in it because the two-word phrase has sufficiently met the equivalent of the ST.

More cases of the category shifts found in the Indonesian translation of Pretext for Mass Murder: the September 30th Movement and Soeharto's coup d'état in Indonesia by John Roosa can be seen in the enclosure. Some cases of shifts, however, are not possible to be analyzed using the Category Shift proposed by Catford because the cases involves semantic, which does not belong to Catford's category. For example, the translation shift cases of and in the SL which means dan in the TT into tapi in the TT which means but in the ST, have tried to meaning telah berusaha in the SL into ingin which means want, seized which means mengepung in the SL into menduduki (past) which means occupied, and many such cases are all related to the shift in semantic meanings, but they can not be 
Analysis of Translation Shift in The Indonesian Translation Dalih Pembunuhan Massal: Gerakan 30 September dan Kudeta Suharto by John Roosa of an English Document Pretext forMass Murder: The September 30th Movement and Suharto's Coup D'état in Indonesia (Sigit Suharjono)

analyzed and categrorized using Catford's for the purpose of translation analysis, for so category.

many cases of translation shifts can not be covered or explained only by Category of

\section{CONCLUSION}

Shifts by Catford.

Based on the category shift analysis of the data collected from the source of data, several conclusions can be drawn as follows:

1. The four types of the category shifts: structure-shifts, class-shifts, unit-shifts, and intra-system-shifts all occur in the Indonesian translation of an English text Pretext for Mass Murder: the September 30th Movement and Soeharto's coup d'état in Indonesia by John Roosa.

2. The structure-shifts are the most to occur, and the intra-system-shift are the least to recur.

3. Some of the cases of the translation shifts do not influence the comprehensibility in the TT, nor do they change the message being communicated.

4. Category shifts can not be used to analyze all the cases of translation shifts.

\section{Suggestion}

In line with the conclusion, it is important that Baker's non-equivalence analysis be used 
CASES OF TRANLATION SHIFTS

\begin{tabular}{|c|c|c|}
\hline No & Cases & Types of Shifts \\
\hline 1. & $\begin{array}{l}\text { Pretext for Mass Murder: The September 30th } \\
\text { Movement and Suharto's Coup d'État in } \\
\text { Indonesia } \\
\text { Dalih Pembunuhan Massal: Gerakan } 30 \\
\text { September dan Kudeta Suharto }\end{array}$ & Structure shift \\
\hline 2. & $\begin{array}{l}\text { The truth about the usurpation must not be } \\
\text { made apparent; it came about originally } \\
\text { without reason and has become reasonable. } \\
\text { Kebenaran tentang perebutan kekuasaan tidak } \\
\text { boleh dibikin jelas; pada mulanya ia terjadi } \\
\text { tanpa alasan tapi kemudian menjadi masuk } \\
\text { akal. }\end{array}$ & $\begin{array}{l}\text { 1. Unit-shifts } \\
\text { 2. Structure-shift. }\end{array}$ \\
\hline 3. & $\begin{array}{l}\text { For historians who have tried to make sense of } \\
\text { the course of modern Indonesian history, a } \\
\text { matter of some frustration is that the most } \\
\text { enigmatic episode happens to be one of the } \\
\text { most significant. } \\
\text { Bagi sejarawan yang ingin memahami } \\
\text { perjalanan sejarah Indonesia modern, hal yang } \\
\text { terkadang menimbulkan rasa frustrasi ialah } \\
\text { justru karena kejadian yang paling misterius } \\
\text { ternyata merupakan salah satu babak kejadian } \\
\text { yang terpenting. }\end{array}$ & $\begin{array}{l}\text { 1. Unit-shifts } \\
\text { 2. Structure-shift }\end{array}$ \\
\hline 4. & $\begin{array}{l}\text { Lieutenant Gen- eral Achmad Yani, and five } \\
\text { generals on his staff were kidnapped from their } \\
\text { homes in Jakarta and trucked to a desolate } \\
\text { grove south of the city. } \\
\text { Letnan Jenderal Ahmad Yani dan lima orang } \\
\text { staf umumnya diculik dari rumah-rumah } \\
\text { mereka di Jakarta, dan dibawa dengan truk ke } \\
\text { sebidang areal perkebunan di selatan kota. }\end{array}$ & $\begin{array}{l}\text { 1. Unit-shift } \\
\text { 2. Class-shift } \\
\text { 3. Structure-shift }\end{array}$ \\
\hline 5. & $\begin{array}{l}\text { The abductors killed Yani and two other } \\
\text { generals in the course of capturing them. } \\
\text { Para penculik membunuh Yani dan dua } \\
\text { jenderal lainnya pada saat penangkapan } \\
\text { berlangsung. }\end{array}$ & $\begin{array}{l}\text { 1. Structure-shift } \\
\text { 2. Unit-shift }\end{array}$ \\
\hline 6. & $\begin{array}{l}\text { Back at the grove sometime later that morning, } \\
\text { the abductors executed the three remaining }\end{array}$ & $\begin{array}{l}\text { 1. Class-shift } \\
\text { 2. Unit-shift }\end{array}$ \\
\hline
\end{tabular}




\begin{tabular}{|c|c|c|}
\hline & $\begin{array}{l}\text { generals and dumped all six corpses down a } \\
\text { well. } \\
\text { Tiba di areal perkebunan beberapa saat } \\
\text { kemudian pada pagi hari itu, mereka } \\
\text { membunuh tiga jenderal lainnya dan melempar } \\
\text { enam jasad mereka ke sebuah sumur mati. }\end{array}$ & \\
\hline 7. & $\begin{array}{l}\text { A lieutenant, grabbed by mistake from the } \\
\text { home of a seventh general, suffered the same } \\
\text { watery subterranean end. } \\
\text { Seorang letnan, yang salah tangkap dari rumah } \\
\text { jenderal ketujuh yang lolos dari pencu- likan, } \\
\text { menemui nasib dilempar ke dasar sumur yang } \\
\text { sama. }\end{array}$ & $\begin{array}{l}\text { 1. Structure-shift } \\
\text { 2. Class-shift }\end{array}$ \\
\hline 8. & $\begin{array}{l}\text { The people behind these killings also seized the } \\
\text { national radio station that morning and } \\
\text { identified themselves over the air as troops } \\
\text { loyal to President Sukarno. Their stated aim } \\
\text { was to protect the president from a clique of } \\
\text { right-wing army generals who were plotting a } \\
\text { coup d'état. } \\
\text { Pagi hari itu juga orang-orang di balik } \\
\text { peristiwa pembunuhan ini pun menduduki } \\
\text { stasiun pusat Radio Republik Indonesia (RRI), } \\
\text { dan melalui udara menya- takan diri sebagai } \\
\text { anggota pasukan yang setia kepada Presiden } \\
\text { Sukarno. Adapun tujuan aksi yang mereka } \\
\text { umumkan ialah untuk melindungi Presiden dari } \\
\text { komplotan jenderal kanan yang akan } \\
\text { melancarkan kudeta. }\end{array}$ & $\begin{array}{l}\text { 1. Structure shift } \\
\text { 2. Unit-shift }\end{array}$ \\
\hline \multirow[t]{2}{*}{9.} & $\begin{array}{l}\text {... commander of an army battalion responsible } \\
\text { for guarding the president, and the name of } \\
\text { their group: the September 30th Movement } \\
\text { (referred to hereafter as "the movement"). } \\
\text {... Komandan Batalyon I Kawal Kehormatan } \\
\text { Cakrabirawa, yang bertanggung jawab } \\
\text { mengawal Presiden, dan menamai gerakan } \\
\text { mereka Gerakan } 30 \text { September (selanjutnya } \\
\text { disebut sebagai G-30-S). }\end{array}$ & 1. Class-shift \\
\hline & $\begin{array}{l}\text { Part of the difficulty in understanding the } \\
\text { movement lies in its defeat, which occurred } \\
\text { before most Indonesians knew it existed. }\end{array}$ & $\begin{array}{ll}\text { 1. } & \text { Structure-shift } \\
\text { 2. Unit-shift } \\
\text { 3. } & \text { Class-shift } \\
\end{array}$ \\
\hline
\end{tabular}




\begin{tabular}{|c|c|}
\hline $\begin{array}{l}\text { Kesulitan memahami G-30-S antara lain karena } \\
\text { gerakan tersebut sudah kalah sebelum } \\
\text { kebanyakan orang Indonesia mengetahui } \\
\text { keberadaannya. }\end{array}$ & \\
\hline $\begin{array}{l}\text { The movement's troops abandoned the radio } \\
\text { station and the central square only twelve hours } \\
\text { after occupying them. } \\
\text { Pasukan G-30-S meninggalkan stasiun RRI dan } \\
\text { Lapangan Merdeka yang sempat mereka } \\
\text { duduki selama dua belas jam saja. }\end{array}$ & 1. Unit-shift \\
\hline $\begin{array}{l}\text { All the rebel troops were either captured or sent } \\
\text { fleeing from Jakarta by the morning of October } \\
2 \text {. } \\
\text { Semua pasukan pemberontak akhirnya } \\
\text { ditangkap atau melarikan diri dari Jakarta pada } \\
\text { pagi hari } 2 \text { Oktober. }\end{array}$ & 1. Structure-shift \\
\hline $\begin{array}{l}\text { In Central Java the movement did not last } \\
\text { beyond October } 3 . \\
\text { Di Jawa Tengah, G-30-S hanya bertahan } \\
\text { sampai } 3 \text { Oktober. }\end{array}$ & 1. Structure-shift \\
\hline $\begin{array}{l}\text { The movement's leaders did not even have the } \\
\text { chance to hold a press conference and pose for } \\
\text { photographers. } \\
\text { Pimpinan G-30-S bahkan belum sempat } \\
\text { mengadakan konferensi pers dan tampil } \\
\text { memperlihatkan diri di depan kamera para } \\
\text { fotografer. }\end{array}$ & $\begin{array}{l}\text { 1. Intra-system shift } \\
\text { 2. Structure-shift }\end{array}$ \\
\hline $\begin{array}{l}\text { By proclaiming the leaders of the movement as } \\
\text { the leaders of a council that held the entire } \\
\text { power of the state, the second statement } \\
\text { showed that what had appeared in the morning } \\
\text { to be an internal army putsch was more like a } \\
\text { coup d'état. } \\
\text { Dengan mengumumkan pimpinan G-30-S } \\
\text { sebagai pimpinan suatu dewan yang memegang } \\
\text { seluruh kekuasaan negara, pengumuman kedua } \\
\text { memperlihatkan bahwa peristiwa yang pada } \\
\text { pagi hari menampak sebagai putsch intern }\end{array}$ & $\begin{array}{l}\text { 1. Intra-system shift } \\
\text { 2. Unit-shift }\end{array}$ \\
\hline
\end{tabular}




\begin{tabular}{|c|c|}
\hline $\begin{array}{l}\text { Angkatan Darat menjadi lebih menyerupai } \\
\text { sebuah kudeta. }\end{array}$ & \\
\hline $\begin{array}{l}\text { The members represented a fairly wide } \\
\text { spectrum of political opinion: Muslim } \\
\text { politicians, midlevel Communist Party figures, } \\
\text { journalists, women, and youth leaders. } \\
\text { Para anggota mewakili aneka macam } \\
\text { pandangan politik yang relatif luas: politisi } \\
\text { Muslim, kader menengah PKI, wartawan, } \\
\text { perempuan, dan pimpinan pemuda. }\end{array}$ & 1. Intra-system shift \\
\hline $\begin{array}{l}\text { Central Java and Yogyakarta were the only } \\
\text { territories outside Jakarta where the movement } \\
\text { manifested itself. } \\
\text { Hanya di Jawa Tengah dan Yogyakarta yang } \\
\text { merupakan wilayah-wilayah di luar Jakarta G- } \\
\text { 30-S mewujud. }\end{array}$ & $\begin{array}{l}\text { 1. Structure-shift } \\
\text { 2. Unit-shift }\end{array}$ \\
\hline $\begin{array}{l}\text { The troops occupied the north, west, and south } \\
\text { sides of the square and left empty the east side, } \\
\text { where the Kostrad building stood. } \\
\text { Pasukan menduduki sisi utara, barat, dan } \\
\text { selatan lapangan tersebut dan membiarkan sisi } \\
\text { timur, tempat markas Kostrad berdiri, kosong. }\end{array}$ & 1. Intra-system shift \\
\hline $\begin{array}{l}\text { Un- like the Jakarta regional command (Kodam } \\
\text { Jaya), Kostrad had no troops permanently } \\
\text { barracked in or around the city. } \\
\text { Berbeda dengan Kodam Jaya, Kostrad tidak } \\
\text { mempunyai pasukan tetap yang diasramakan di } \\
\text { dalam atau sekitar kota. }\end{array}$ & 1. Intra-system shift \\
\hline $\begin{array}{l}\text { All subsequent books sponsored by the } \\
\text { government, such as the } 1994 \text { white book, } \\
\text { based much of their narrative on Sjam's } \\
\text { testimony. } 24 \\
\text { Semua buku yang disponsori pemerintah, } \\
\text { seperti misalnya buku putih 1994, mendasarkan } \\
\text { uraian mereka pada kesaksian Sjam itu. }\end{array}$ & 1. Intra-system shift \\
\hline
\end{tabular}

